\title{
MODEL SITUS E-COMMERCE TANAMAN HIAS
}

\author{
Putra Umamul Musthofa ${ }^{1}$, Yusuf Amrozi ${ }^{2}$ \\ ${ }^{1,2}$ Universitas Islam Negeri Sunan Ampel Surabaya \\ Ih06219013@student.uinsby.ac.id, 2yusufamrozi@uinsby.ac.id
}

\begin{abstract}
Along with the development of the times, the existence of trading through an online sistem is growing rapidly. People who originally had the attraction of offline shopping began to shift to the online sistem. Today, just by browsing the internet, everyone can afford what they want including ornamental plants. There are so many conveniences that are obtained with the ornamental plant e-commerce site such as; saving transportation costs, ease of transactions, transaction security due to the existence of a 3rd party, being able to choose ornamental plants as desired, etc.

The purpose of this paper is to build an e-commerce site for ornamental plants as a means of buying and selling ornamental plants online. The design result made are the visitor, member, and admin page design. The method in designing this e-commerce site is the waterfall method. The design of each menu for visitors, members, and admins is differentiated from access rights given. This is in ilne with the analysis of sistem user requirements.
\end{abstract}

Keywords: Information Sistem Design; E-Commerce; Agrobussiness; ERD (Entity Relationship diagram); System Requirement Analysis; Sistem Modeling.

\begin{abstract}
Abstrak
Seiring berkembangnya zaman, adanya perdagangan melalui sistem online berkembang secara pesat. Masyarakat yang semula memiliki daya tarik berbelanja secara offline mulai bergeser ke sistem online. Saat ini hanya dengan menjelajah internet, semua orang mampu membeli apa yang mereka inginkan termasuk tanaman hias. Banyak sekali kemudahan yang didapat dengan adanya situs e-commerce tanaman hias seperti ; hemat biaya transportasi, kemudahan bertransaksi, keamanan transaksi karena adanya pihak ke-3, dapat memilih tanaman hias sesuai yang diinginkan, dan lain sebagainya. Tujuan dari penulisan ini untuk membangun situs e-commerce tanaman hias sebagai sarana jual beli online tanaman hias. Metode dalam merancang bangun situs e-commerce ini menggunakan metode waterfall. Hasil rancangan yang dibuat adalah desain halaman pengunjung, member, dan admin. Rancangan dari setiap menu pengunjung, member, dan juga admin dibedakan dari hak akses yang diberikan. Hal ini sejalan dengan analisis kebutuhan pengguna sistem.
\end{abstract}

Kata kunci: Rancang Bangun Sistem Informasi; E-Commerce; Bisnis Tanaman Hias; ERD (Entity Relationship Diagram); Analisis Kebutuhan Sistem, Pemodelan Sistem.

\section{PENDAHULUAN}

Menurut data statistik dari website https://www.internetworldstats.com/stats.htm menyatakan bahwa pengguna internet di dunia khususnya di asia sangatlah banyak. Seiring dengan penggunaan internet yang begitu pesat, kecenderungan serta kebiasaan manusia mulai berpindah ke ranah online. Hal ini kemudian menuai dampak positif serta negatif. Salah satu dampak positifnya yaitu penggunaan marketplace atau e-commerce yang sangat merombak tatanan pasar di Indonesia khususnya. Karena kebiasaan lama dalam berbelanja offline mulai tergantikan dengan berbagai kemudahan berbelanja secara online. E-Commerce dapat terjadi antara organisasi bisnis dengan konsumen, meliputi penggunaan Internet dan World Wide Web untuk penjualan produk dan pelayanan untuk konsumen (Doolin, et al., 2005).

Berbagai kemudahan berbelanja online diantaranya yaitu; hemat biaya transportasi, hemat waktu, hemat tenaga, terjamin kualitas barang, terjamin keamanan barang, serta beberapa hal mengenai informasi dari barang yang akan dibeli termasuk tanaman hias. Terlepas dari kemudahan yang didapat, berbelanja online juga dapat menuai efek 
negatif apabila melakukan kesalahan seperti berbelanja illegal, blackmarket, melalui media sosial dan lain sebagainya. Tetapi dengan adanya e-commerce yang resmi akan melepaskan segala kekurangan dari berbelanja online. Seperti terkendala jarak dan juga adanya pihak ke-3 untuk menjamin transaksi yang dilakukan.

Dewasa ini, di Indonesia tanaman hias sedang digandrungi oleh banyak peminat. Terutama mereka yang mengalami dampak dari pandemi yang menyebabkan sebagian besar orang harus tetap terjaga di rumah masingmasing. Tanaman hias dapat menjadi hobi baru yang mengasyikan dan menambah keindahan rumah tentunya. Disisi lain, tanaman hias juga dapat menjadi usaha tambahan dikala pandemi. Melihat banyak sekali peminatnya saat ini. Tetapi sebagian orang, mengikuti trend tanaman hias hanya sekedar ikut-ikutan saja tanpa mengetahui informasi apapun.

Oleh karena itu, perlu dibuat sebuah sistem informasi untuk mengelompokkan jenis tanaman hias berdasarkan taksonominya. Selain itu, di dalam sistem informasi juga akan ditampilkan sejarah, nama lain atau nama daerah, dan karakteristik dari tanaman hias tersebut. Sehingga semua orang dapat mempelajari jenis tanaman hias beserta asal usulnya terlebih dahulu sebelum mereka memilikinya. Dengan adanya model situs e-commerce tanaman hias orangorang juga dapat menjual serta membeli tanaman hias. Sehingga fungsinya tidak hanya sekedar menginformasikan sebuah tanaman hias, tetapi menjadi marketplace yang baru untuk tanaman hias.

\begin{tabular}{|c|c|c|c|c|c|c|}
\hline \multicolumn{7}{|c|}{$\begin{array}{l}\text { WORLD INTERNET USAGE AND POPULATION STATISTICS } \\
2020 \text { Year-Q3 Estimates }\end{array}$} \\
\hline World Regions & $\begin{array}{l}\text { Population } \\
\text { ( } 2020 \text { Est.) }\end{array}$ & $\begin{array}{l}\text { Population } \\
\% \text { of World }\end{array}$ & $\begin{array}{l}\text { Internet Users } \\
30 \text { Sept } 2020\end{array}$ & $\begin{array}{c}\text { Penetration } \\
\text { Rate (\% Pop.) }\end{array}$ & $\begin{array}{c}\text { Growth } \\
2000-2020\end{array}$ & $\begin{array}{l}\text { Internet } \\
\text { World \% }\end{array}$ \\
\hline Africa & $1,340,598,447$ & $17.2 \%$ & $631,940,772$ & $47.1 \%$ & $13,898 \%$ & $12.8 \%$ \\
\hline Asia & $4,294,516,659$ & $55.1 \%$ & $2,555,636,255$ & $59.5 \%$ & $2,136 \%$ & $51.8 \%$ \\
\hline Europe & $834,995,197$ & $10.7 \%$ & $727,848,547$ & $87.2 \%$ & $593 \%$ & $14.8 \%$ \\
\hline Latin America / Caribbean & $654,287,232$ & $8.4 \%$ & $467,817,332$ & $71.5 \%$ & $2,489 \%$ & $9.5 \%$ \\
\hline Middle East & $260,991,690$ & $3.3 \%$ & $184,856,813$ & $70.8 \%$ & $5,527 \%$ & $3.7 \%$ \\
\hline North America & $368,869,647$ & $4.7 \%$ & $332,908,868$ & $90.3 \%$ & $208 \%$ & $6.8 \%$ \\
\hline Oceania / Australia & $42,690,838$ & $0.5 \%$ & $28,917,600$ & $67.7 \%$ & $279 \%$ & $0.6 \%$ \\
\hline WORLD TOTAL & $7,796,949,710$ & $100.0 \%$ & $4,929,926,187$ & $63.2 \%$ & $1,266 \%$ & $100.0 \%$ \\
\hline \multicolumn{7}{|c|}{$\begin{array}{l}\text { NOTES: (1) Internet Usage and World Population Statistics estimates are for October 20, 2020. (2) CLICK on each world region } \\
\text { name for detailed regional usage information. (3) Demographic (Population) numbers are based on data from the United Nations } \\
\text { Population Division. (4) Internet usage information comes from data published by Nielsen Online, by the International } \\
\text { Telecommunications Union, by GfK, by local ICT Regulators and other reliable sources. (5) For definitions, navigation help and } \\
\text { disclaimers, please refer to the Website Surfing_Guide. (6) The information from this website may be cited, giving the due credit } \\
\text { and placing a link back to www.internetworldstats.com. Copyright } @ 2020 \text {, Miniwatts Marketing Group. All rights reserved } \\
\text { worldwide. }\end{array}$} \\
\hline
\end{tabular}

Gambar 1. World Internet Usage and Population Statistics

\section{KERANGKA TEORI}

\subsection{Rancang Bangun Sistem Informasi}

Rancang Bangun adalah kegiatan menciptakan dan membuat suatu aplikasi ataupun sistem yang belum ada pada suatu instansi atau objek tertentu. Sedangkan Sistem Informasi adalah kumpulan dari elemen sistem informasi seperti perangkat keras, perangkat lunak, komputer, user, dan data yang di manajemen menghasilakan sebuah informasi. Rancang bangun sendiri memiliki tahapan-tahapan dalam perancangannya yang disebut dengan SDLC (Sistem Development Life Cycle) (Pressman, 2010). 


\subsection{Model Situs E-Commerce}

E-Commerce merupakan segala aktivitas jual beli melalui media elektronik. Istilah tersebut digunakan untuk mendeskripsikan segala transaksi yang menggunakan media elektronik seperti smartphone dan komputer." $E$ commerce is dynamic set of technologies, applications, and business process that link enterprises, costumers, and communities through electronic transactions and electreonic exchange of goods, servicesm, and information" (Baum, 1999).

Sedangkan, model situs e-commerce atau lebih familiar dikenal sebagai marketplace adalah sarana untuk menghubungkan antara penjual dengan pembeli melalui aplikasi maupun web. Hal ini sangat populer belakangan ini dikarenakan penjual dapat melampaui batasan-batasan yang menghambat pemasaran serta memudahkan pembeli melakukan transaksi secara cepat, aman, praktis, dan tentunya lebih efisien.

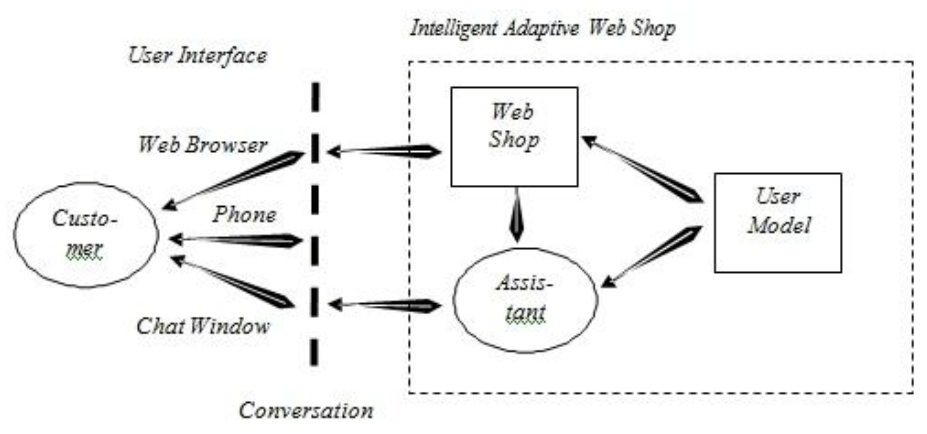

Gambar 2. Struktur Sistem E-Commerce Berbasis Web (Aberg dan Shahmehri, 2000)

\subsection{Desain Situs E-commerce}

Laudon dan Laudon (2006) "Web merupakan sebuah sistem dengan stardar yang diterima secara universal untuk menyimpan, mengambil, menyusun, dan menampilkan informasi dalam sebuah jaringan. Informasi ditampilkan dalam bentuk halaman elektronik yang dapat berisi teks, grafis, animasi, audio, dan video". Supaya menghasilkan situs pemasaran yang efektif, perlu memperhatikan analisis 7C (Burner dan Kumar, 2000).

1. Context, memuat desain dan layout dari situs tersebut.

2. Content, memuat isi materi situs.

3. Community, memuat bagaimana situs tersebut memungkinkan interaksi antar sesama user.

4. Customization, memuat kemampuan situs untuk disesuaikan dengan masing-masing user.

5. Communication, memuat bagaimana situs tersebut memungkinkan komunikasi dua arah.

6. Connection, memuat bagaimana situs tersebut terhubung dengan situs lain.

7. Commerce, memuat situs untuk memungkinkan adanya transaksi komersial.

Namun Yang. Et al. (2008) menambahkan menjadi 8C dari semula 7C dan menciptakan referensi dengan collaboration. Adanya penambahan unsur collaboration memungkinkan konsumen dapat memberikan saran, komentar, dan lain sebagainya. 


\subsection{Entity Relationship Diagram (ERD)}

Menurut Sukamto \& Shahaludin (2013), ERD merupakan diagram pemodelan basis data relasional. Sehingga sebelum membuat sebuah database diperlukan konsep perancangan yang disebut ERD. Tujuan dibuatnya ERD juga sebagai bahan acuan dalam pengembangan database.

\section{METODOLOGI}

\subsection{Jenis penelitian}

Pada artikel ini penulis menggunakan jenis penelitian deskriptif kualitatif. Deskriptif kualitatif merupakan jenis penelitian yang mendeskripsikan, menggambarkan, melukiskan, menjabarkan, serta menganalisis kejadian, fakta, fenomena maupun keadaan sosial. Metode kuantitatif juga disebut metode tradisional, hal ini dikarenakan metode tersebut sudah lama digunakan (Sugiyono, 2012).

\subsection{Teknik pengumpulan data}

Pengumpulan data yang dilakukan melalui beberapa cara sebagai berikut:

1. Penelitian kepustakaan, yaitu meneliti dari jurnal, buku, dan sumber literasi lainnya. penelitian observasi.

2. Pengumpulan data dengan cara mengamati dan mencari data secara sistematis mengenai ciri-ciri tanaman hias.

3. Wawancara, yaitu kegiatan mewawancarai secara langsung petani tanaman hias untuk menggali informasi.

\subsection{Teknik Analisi Data}

Teknik analisis data yang dilakukan penulis yaitu teknik analisis kualitatif. Penulis melakukan analisis pada kebun tanaman hias untuk menambah gagasan atau ide yang dibutuhkan dalam penulisan artikel, serta melakukan penelitian pada jurnal-jurnal yang relevan dengan judul artikel.

\subsection{Metode Perancangan}

Pada perancangan model situs e-commerce penulis mengangkat metode pengembangan Waterfall. Metode ini melakukan pendekatan secara urut dan sistematis.

\subsubsection{Tahap Perancangan Waterfall}

\section{a. Perencanaan}

Pada proses perencanaan ada beberapa hal yang perlu diperhatikan dan dipersiapkan secara matang sebelum membuat suatu sistem informasi.

1) Feasility study

Studi kelayakan atau feasility study dilakukan untuk memepertimbangkan seberapa besar pengaruh dan dampak yang dihasilkan dari sistem informasi yang dibuat nantinya. Apakah benar-benar layak dan membantu user memenuhi kebutuhannya.

2) Budget

Anggaran pembuatan sistem informasi harus dibuat sesuai dengan kebutuhan dan jangan sampai over budget. Hal ini akan mengakibatkan terganggunya proses perancangan yang dapat mengakibatkan kegagalan. Selain itu, mencari sumber dana yang sesuai adalah hal yang utama untuk mendukung proses perancangan.

3) Sumber daya 
Mulai mencari sumber daya manusia yang kompeten pada bidangnya. Ahli IT akan menangani masalah pengembangan dan maintenance, Sistem analyst akan menangani bagian testing dan Analisa.

4) Cakupan

Merencanakan cakupan pengguna hingga seberapa banyak, untuk mengurangi resiko adanya kesulitan dalam mengakses sistem informasi nantinya.

5) Alokasi waktu

Merencanakan lamanya waktu yang dibutuhkan untuk membangun sebuah sistem informasi. Sehingga dapat diselesaikan tepat waktu sesuai yang diinginkan oleh perusahaan.

b. Analisa

Analisa sistem adalah tahap di mana beberapa aktivitas dilakukan seperti.

1) Melakukan studi literatur guna mendapatkan kasus yang bisa ditangani oleh sistem.

2) Melakukan Brainstorming dalam tim pengembang terhadap kasus yang paling tepat dimodelkan dengan sistem.

3) Mengklasifikasikan masalah peluang dan solusi yang kemungkinan dapat diterapkan pada kasus tersebut.

4) Melakukan Analisa kebutuhan pada sistem dan membuat constrain pada sistem.

5) Mendeskripsikan kebutuhan sistem.

c. Desain

Membuat beberapa desain yang dibutuhkan seperti

1) Membuat desain database.

2) Membuat desain diagram proses.

3) Membuat desain Screen Layout.

4) Membuat desain Report Layout.

\section{d. Pengembangan}

Pengembangan dilakukan untuk menerapkan hasil Analisa dan desain-desain yang telah dibuat. Beberapa hal yang perlu dilakukan adalah :

1) Menganalisa data dan fungsi pada sistem.

2) Menganalisa interaksi objek dan membuat skema database.

3) Merancang user interface.

4) Membuat flow sederhana.

5) Hindari penggunaan hard code.

6) Dokumentasi disetiap program.

7) Meringkas kumpulan source code.

8) Biasakan meletakkan source code di flow logic.

e. $\quad$ Testing

Testing adalah tahap terpenting pada SDLC pembuatan sistem informasi atau software. Beberapa hal yang akan diujikan antara lain.

1) Melakukan pengujian pada kualitas kode. 
2) Melakukan pengujian terhadap fungsionalitas sistem.

3) Melakukan pengujian integrasi.

4) Melakukan pengujian pada performa sistem.

5) Melakukan pengujian terhadap keamanan sistem.

Terdapat perangkat penguji bernama Continuous Integration seperti Codeship yang dapat membantu melakukan pengujian terhadap sistem agar tidak ada hal-hal atau part yang terlewati.

\section{f. $\quad$ Proses Implementasi}

Pada proses implemantasi dilakukan beberapa hal sebagai berikut.

1) Menentukan penggunaan hardware dan software.

2) Merancang pengembangan sistem yang baru.

3) Memelihara dan meningkatkan sistem yang baru apabila diperlukan.

4) Melakukan penilaian terhadap kelayakan sistem yang sudah diujikan.

5) Menganalisis pemecahan masalah dalam pengembangan sistem.

g. Pengoperasian dan pemeliharaan

Pada tahap pemeliharaan sistem dilakukan beberapa hal sebagai berikut.

1) Memperbaiki celah dan kerusakan pada sistem yang baru.

2) Melakukan sistem maintenance.

3) Melakukan backup and recovery data pada sistem yang baru.

4) Melakukan data archive pada sistem yang baru.

\section{HASIL DAN PEMBAHASAN}

\subsection{Analisis Kebutuhan Sistem}

Analisis kebutuhan sistem mencakup hak akses yang akan diberikan kepada pengunjung, member, dan admin. Masing-masing pengguna akan diberikan hak akses sesuai dengan kebutuhan mereka. Hak akses tersebut antara lain sebagai berikut:

1. Admin

- Mendapat akses untuk mengelola website.

- Mendapat akses mengenai daftar member.

- Mendapat akses mengelola transaksi pemesanan tanaman hias.

- Mendapat akses memanajemen sistem.

2. Member

- Mendapat akses login dan password.

- Mendapat akses melakukan transaksi.

- Mendapat akses konfirmasi pembayaran.

- Mendapat akses informasi produk tanaman hias.

- Mendapat akses layanan testimoni. 


\section{Pengunjung}

- Mendapat akses informasi produk tanaman hias.

- Mendapat akses layanan melihat testimoni.

\subsection{Rancangan Entity Relationship Diagram}

Entity Relationship Diagram pembuatan situs e-commerce tanaman hias. Entity Relationship Diagram dapat ditunjukkan pada gambar 2 .

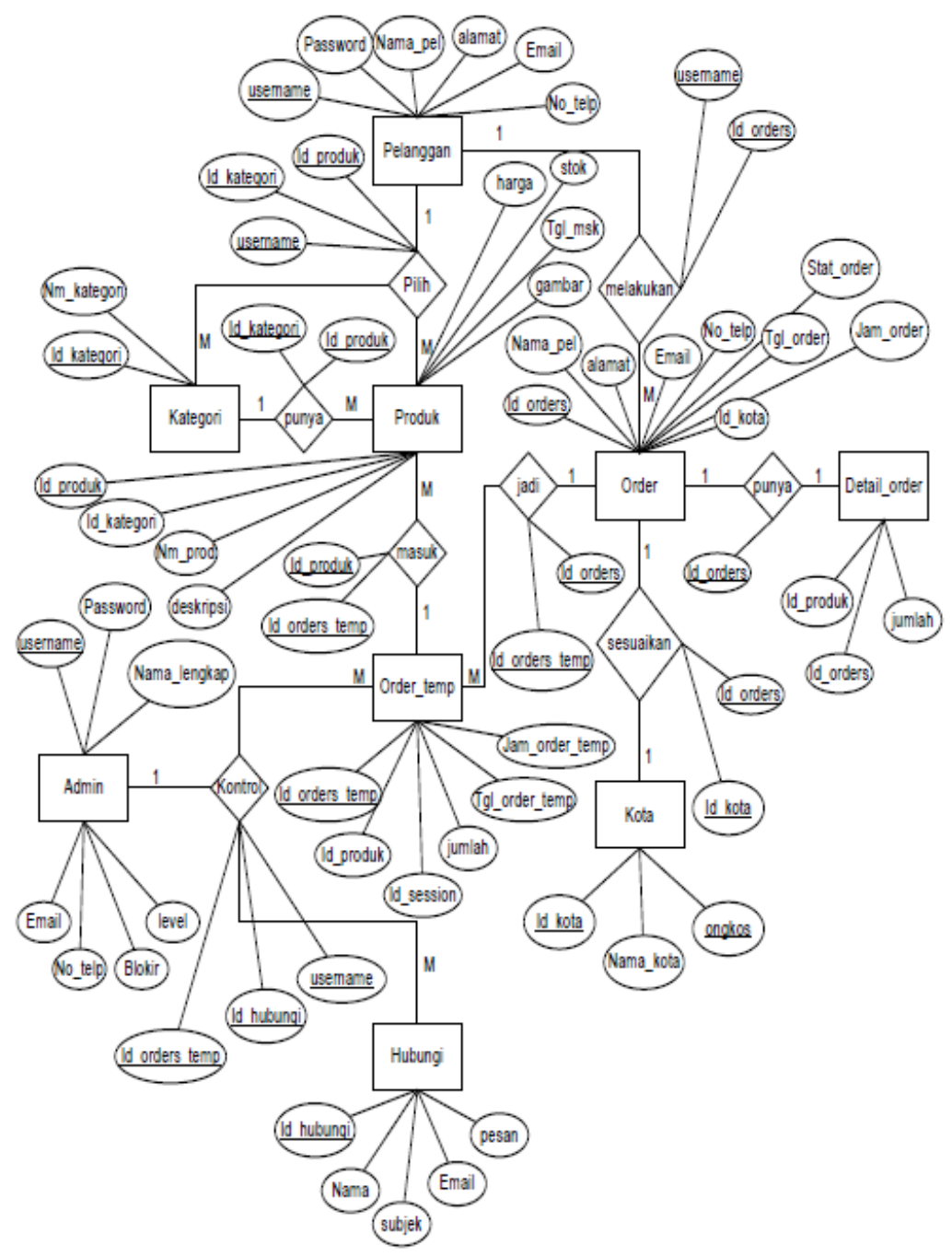

Gambar 3. Entity Relationship Diagram (ERD)

\subsection{Activity Diagram}

1. Prosedur Pemesanan

Setelah pengunjung berhasil login dan menjadi member, maka member dapat melakukan pemesanan pada produk tanaman hias yang diminati. Member dapat mengeklik tombol beli dan melakukan pemilihan pada jasa pengiriman, cara pembayaran, dan juga mengisi data penerima apabila melakukan pemesanan dengan menggunakan atas nama orang lain atau bukan member. 


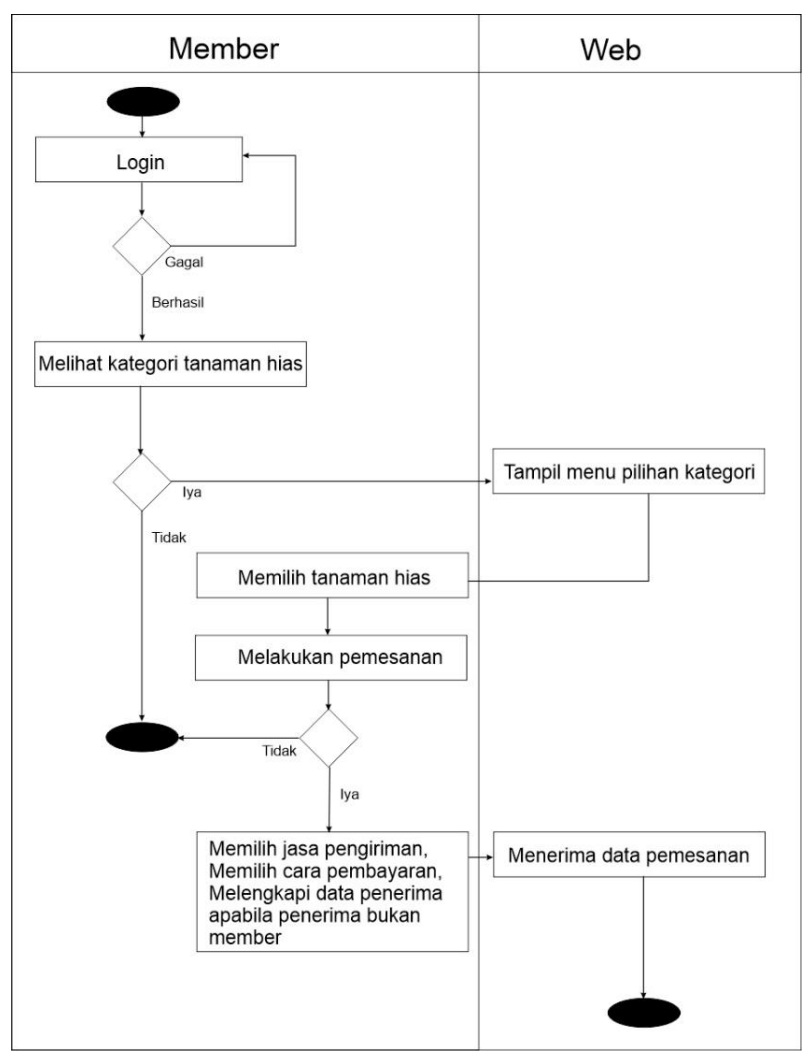

Gambar 4. Activity Diagram Pemesanan

2. Prosedur pembayaran

Setelah mendapat nomor pemesanan, member akan diberikan tenggang waktu melakukan pembayaran selama 1 x24 jam. Apabila melebihi tenggat waktu yang diberikan, pemesanan akan otomatis dibatalkan. Sedangkan jika sudah melakukan pembayaran, member akan mendapat informasi pengiriman tanaman hias.

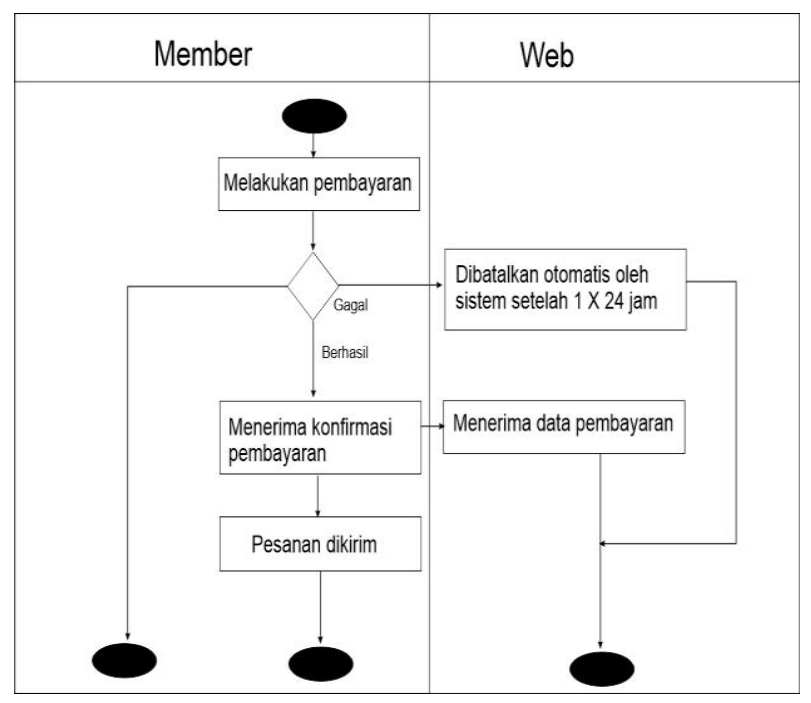

Gambar 5. Activity Diagram Pembayaran 
3. Prosedur laporan

Laporan tentang data pemesanan, pembayaran, dan pengiriman akan diberikan kepada admin dan juga penjual. Dengan adanya informasi laporan pengiriman, member nantinya akan dapat melakukan tracking pada tanaman hias yang mereka beli. Sehingga meningkatkan rasa percaya kepada member mengenai keamanan tanaman hias yang mereka beli.

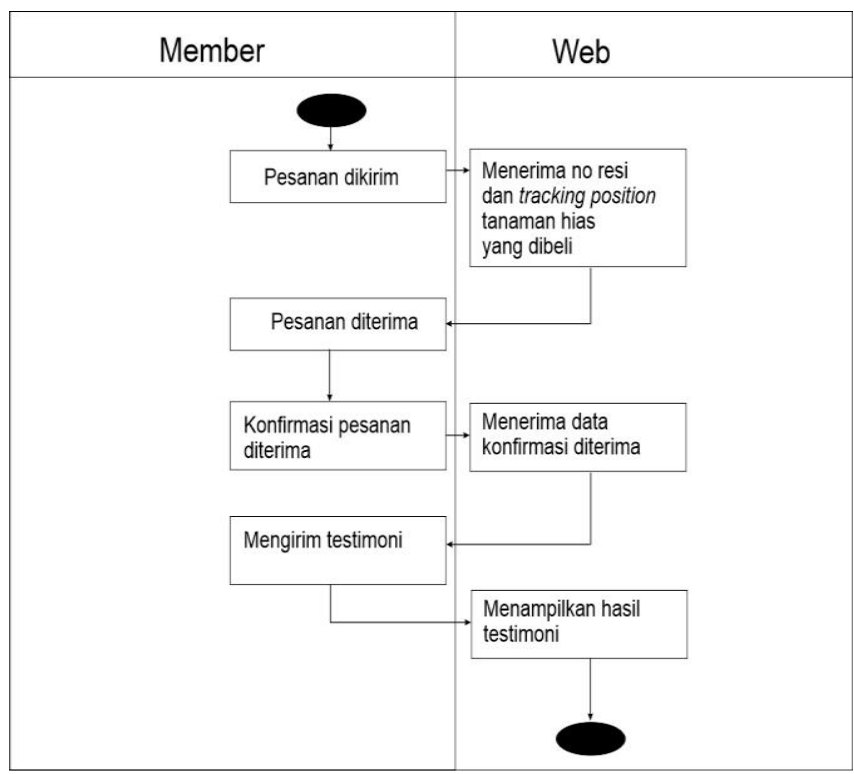

Gambar 6. Activity Diagram Laporan

\subsection{Rancangan Fitur}

1. Fitur Halaman Admin

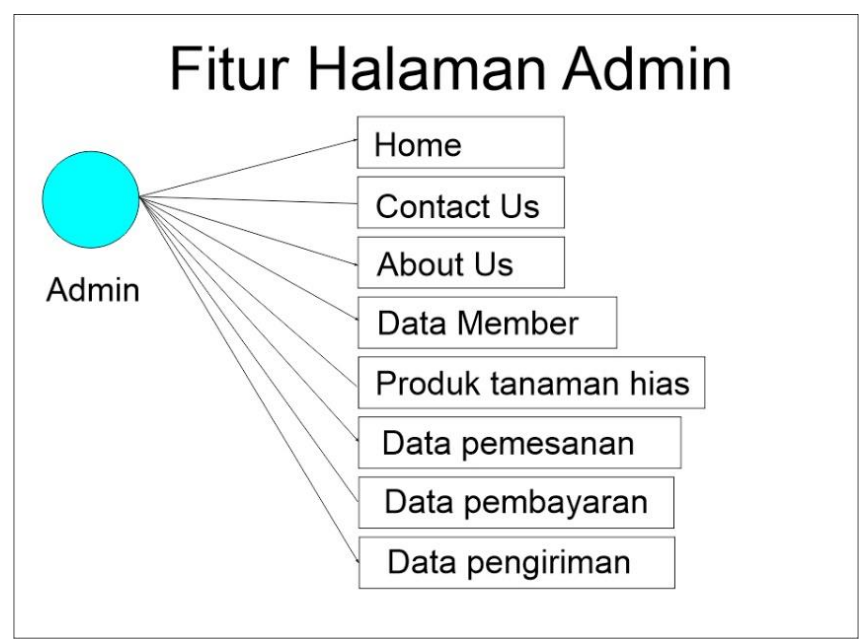

Gambar 7. Fitur Halaman Admin 
2. Fitur Halaman Member

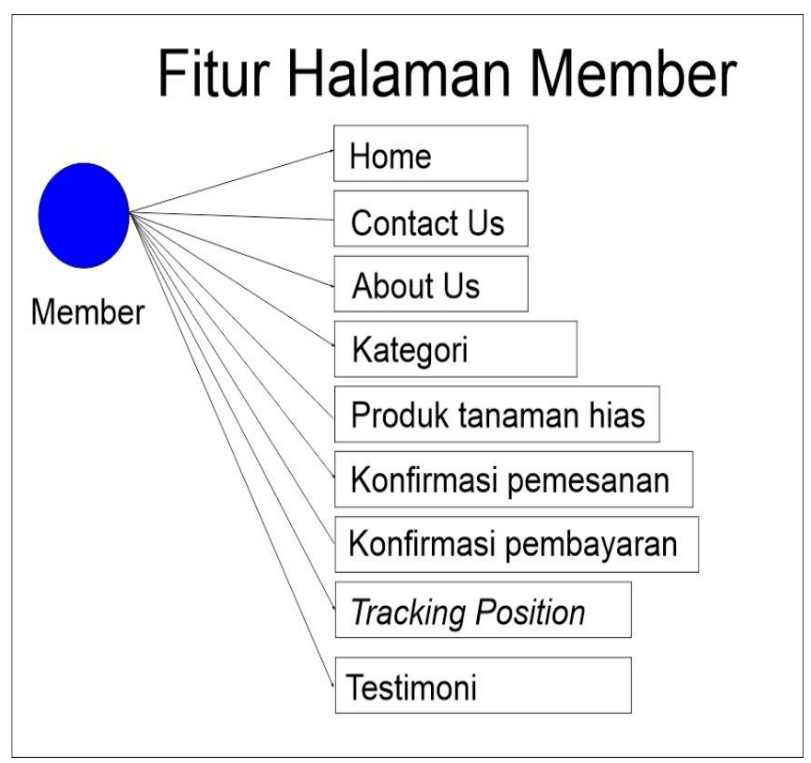

Gambar 8. Fitur Halaman Member

\subsection{Implementasi}

1. Form Pendaftaran Member

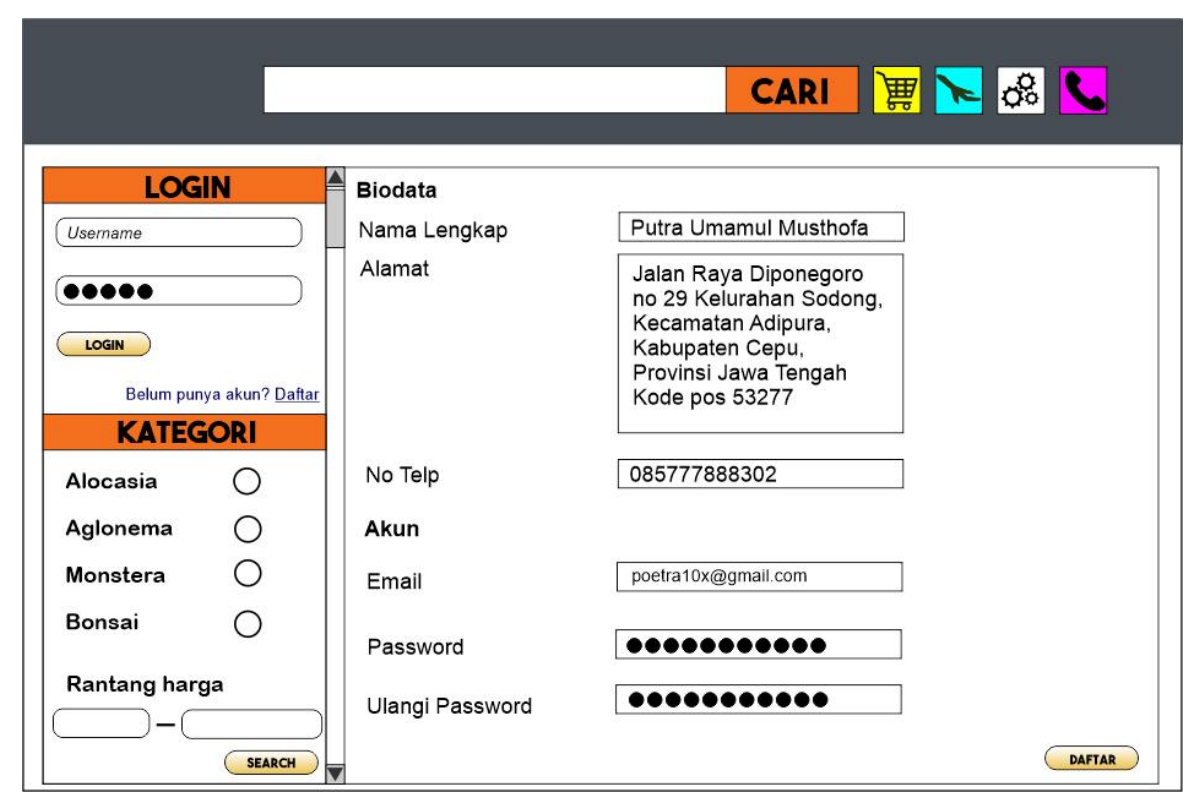

Gambar 9. Tampilan Form Pendaftaran 
2. Keranjang Belanja

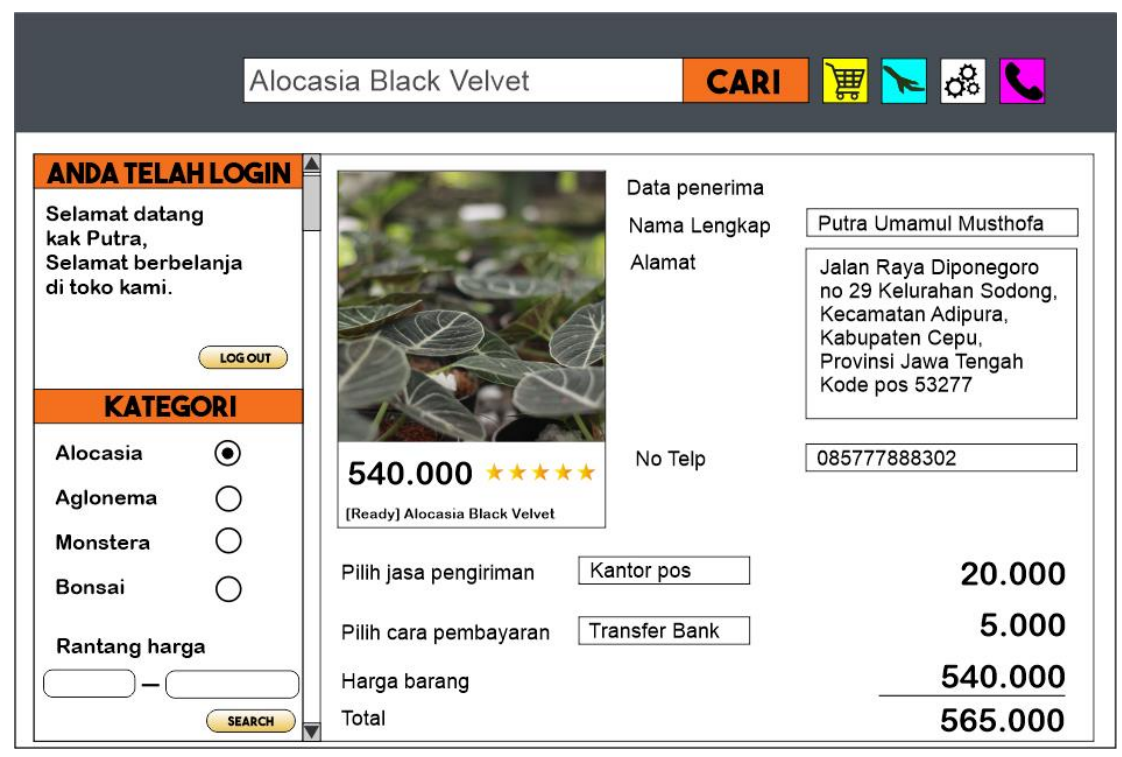

Gambar 10. Tampilan Keranjang Belanja

\section{KESIMPULAN}

Hal utama yang dilakukan sebelum membuat rancang bangun sebuah sistem informasi adalah mencari referensi maupun informasi yang terkait dengan sistem informasi yang akan dibuat. Selanjutnya mulai mengalisis hal-hal yang dibutuhkan untuk dimuat dalam sistem informasi dan melakukan perencanaan dan target dari sistem informasi. Pada perancangan atau desain sebuah e-commerce perlu diperhatikan fitur-fitur yang memudahkan pengguna dalam menggunakan sistem. Selain hal itu, perlu desain yang interaktif, inovatif, serta eye-catching sehingga pengguna juga tidak bosan Ketika hendak berbelanja.

\section{DAFTAR PUSTAKA}

Aberg, J., and Shahmehri, N., 2000. The Role of Human Web Assistants in E-Commerce: An Analysis and A Usability Study. Internet Research Electronic Networking Applications and Policy

Doolin, Bill., Dillon, Stuart., Thompson, Fiona., dan Corner, James L. 2005. Perceived Risk, The Internet Shopping

Experience and Online Purchasing Behavior : A New Zealand Perspective. Journal of Global Information Management. Vol 13, No 2..

Baum, David., 1999. E-Commerce. Jakarta: PT. Gramedia Pustaka Utama

Bruner, G.C., dan Kumar, A., 2000. Web Commercials And Advertising Hierarchy of Effects.

https://www.internetworldstats.com/stats.htm

Laudon. Kenneth C., dan Laudon. Jane P., 2006. Management Information System, 10th ed, Jakarta: Salemba Empat. Pressman, Roger S., 2010. Rekayasa Perangkat Lunak: Pendekatan Praktisi (Buku Satu). Yogyakarta: Andi.

Sugiyono., 2012. Memahami Penelitian Kualitatif. Bandung: Alfabeta.

Sukamto., Shalahuddin., 2013. Analisa dan Desain Sistem Informasi. Yogyakarta: Andi Offset.

Yang, T. A., D. J. Kim, V. Dhalwani dan Tri K. Vu., 2008. The 8C Framework as a reference Model for Collaborative Value Webs in the Context of Web 2.0. Vol 41, hal 7, Texas. 